Article

\title{
The Muslim Council of Britain: Progressive Interlocutor or Redundant Gatekeeper?
}

\author{
Harun Khan, Hassan Joudi and Zahraa Ahmed * \\ Muslim Council of Britian, P.O. Box 57330, London E1 2WJ, UK \\ * Correspondence: media@mcb.org.uk
}

Received: 12 February 2020; Accepted: 10 August 2020; Published: 17 September 2020

\begin{abstract}
Since its inception in 1997, the Muslim Council of Britain (MCB) has evolved to become one of the most enduring British Muslim organisations. It is a representative body for over 500 member bodies ('affiliates') including mosques, schools and charities. During the course of the last two decades, it has been subject to external comment and sometimes critique by academics, media commentators, policy-makers, and others. This special issue of the journal Religions has provided a welcome opportunity for the current leadership of the $\mathrm{MCB}$ to write about the organisation from 'within', based on their long-standing time volunteering with it. This paper is based on an oral history methodology involving extended interviews with the oversight of a research director, supplemented by reference to existing academic and other sources. Therefore this paper is essentially a type of 'edited transcript' aggregated wholly from a series of first person interviews undertaken with the current senior elected leaders of MCB; reorganised for clarity and drafted out with added 'prose' allowing for it to be presented in essay form. The result is the first documented 'insider' perspective on the ways in which the MCB has tackled issues such as internal governance, the challenge of 'representation' in view of the diversity of British Muslim communities, changing relationships with government, and policy work. It becomes apparent through the paper that the MCB has matured into a constructively self-critical, pro-active, and more strategically professional body, that contributes to the flourishing of Muslim communities and the place of Islam in British society. The production of the paper is itself an indicator of the growing confidence and capacity of the MCB, and its ability to contribute positively to academic discourse and debate about Muslims in Britain.
\end{abstract}

Keywords: British Muslims; faith-based representation; leadership; umbrella organisation; MCB; civil society; political participation

\section{Genesis and Early Evolution of the MCB}

The MCB was inaugurated on 23rd November 1997 at Brent Town Hall in North London at a conference attended by representatives of more than 250 Muslim organisations from all parts of the UK, including Wales, Scotland and Northern Ireland. It was successful in ensuring representation from bodies reflecting a wide range of ethnic and theological backgrounds, and the interests of extant regional associations at the time, such as the Lancashire Council of Mosques and the Federation of Muslim Organisations of Leicestershire. The launch followed a consultation period that had commenced in 1994 which brought various key individuals and organisations together under the working name NICMU (National Interim Committee on Muslim Unity). This body circulated surveys in English as well as community languages, and held meetings with the major national Muslim organisations at the time, such as the Union of Muslim Organisations (UMO), the Muslim Parliament, the UK Action Committee on Islamic Affairs (UKACIA), as well as with influential Muslim activists.

The nationwide survey conducted by NICMU in 1995 concluded "increasingly, co-ordination and unity is now seen as a question of the very survival of the community" (NICMU 1996, p. 3). 
The community's expectations from a 'co-ordinating body' included lobbying, liaison with the media, leadership, and delivery of specific programmes (ibid). The survey also conveyed a feeling that existing national Muslim bodies were not sufficiently broad-based nor with opportunities for electoral changes of leadership. It arrived at the understanding that:

“... various attempts have been made over the years to achieve some measure of coordination with some positive results. But it is probably true to say that these attempts have not kept pace with the rapid growth and rich diversity of the community ... " (ibid)

Academic analysis of the situation at the time argued that other so-called 'representative' bodies, such as the UMO, were "ahead of their time" (Nielsen 2004, p. 49), or insufficiently linked to the schools of thought that predominated in Britain's largely South Asian Muslim communities (Gilliat-Ray 2010, p. 109). Either way, there were powerful internal and external forces at work that served as a catalyst for renewed efforts to find a new 'voice' for Muslims in Britain, shaped by national and international politics.

The final meeting of NICMU took place in Bradford on 25 May 1996, hosted by Bradford Council for Mosques. At this meeting, an outline constitution was agreed and the name 'The Muslim Council of Britain (MCB)' was chosen from seven proposals. Thereafter a preparatory committee was formed to finalise the constitution, invite more organisations to join and make preparations for the formal launch (Bari 2018). The agreed constitution adopted in November 1997 begins with references to Quranic verses relating to unity (3:103), enjoining what is right (3:110) and supporting one another (5:2). A commitment to being independent, cross-sectarian, broad-based and thereby representative were priorities that $\mathrm{MCB}^{\prime}$ s founding members drafted into its constitution. There were specific references to the MCB being obliged to "base its policies and decisions on consensus and the largest practicable measure of common agreement" and to have in place a "system of representation and accountability"1.

The representative membership model that emerged in the MCB Constitution was based on an analysis of the constitutions of existing regional and national Muslim representative organisations, both in the UK and the US. Moreover, the constitutions of the umbrella bodies of other faiths groups were also examined. In this way, the MCB's foundations can be regarded as organic, grassroots and bottom-up in origin, and based on existing best practice available at the time (Peedziwiatr 2007, p. 270).

Next the challenge of finding consensus amid the diverse communities that make up the British Muslim population was never going to be an easy task, and from the outset, the MCB never claimed to be 'the' only representative body. Rather, it sought to work with a range of Muslim civil society organisations. Sometimes this has led to rivalry, but often partnership and/or membership as an MCB 'affiliate'. Other bodies have taken up specialised niches which have come to complement the MCB's principal efforts, becoming part of the MCB 'ecosystem'. The current MCB Secretary-General (and co-author of this paper) was himself present at the 1997 inauguration as a young volunteer steward, and he is clear that the task of providing a representative, uniting and co-ordinating role for British Muslim communities today remains the MCB's core raison d'etre, as it was from its inception.

In addition to the critique levelled at some of the predecessors of the MCB, it is important to appreciate the wider political climate that saw the leaders of various Muslim communities come together in the period 1994-1997. There was a particular convergence of national and international circumstances that created a driver for the creation of a stronger representative national body, from the Satanic Verses affair, to the ongoing war and genocide in Bosnia. The Muslim periodical ' $Q$ News' reported advice given to Muslim activists at the time by the then Home Secretary, Michael Howard, to the effect that they should "speak with one voice should they wish to exercise more influence over government" (McLoughlin 2005, p. 60). Recognition of the need for a strong organisation at a national level was clear, "... we felt that we needed to organise otherwise nobody is going to listen to us", asserted one of the early MCB Office Bearers.

1 The Muslim Council of Britain, 'MCB Constitution with Amendments Adopted at Fifteenth Annual General Meeting 2012', 2012, www.mcb.org.uk/wp-content/uploads/2016/03/MCB_Constitution_FINAL-2013.pdf. 
Indeed the landscape of British Muslim communities and how they engaged in public life and social activism was beginning to change from the early 1990s. Much of the important groundwork was laid by the UK Action Committee on Islamic Affairs (UKACIA) which was able to tap into the expertise of a new generation of Muslim professionals (McLoughlin 2005). UKACIA produced well-argued documents such as, Muslims and the Law in Multi-faith Britain: Need for Reform (UKACIA 1993), which was a memorandum submitted to the Home Secretary in 1993. In 1997 UKACIA prepared an eleven-page policy document Elections 1997 and British Muslims_For a Fair and Caring Society. The MCB took up this mantle of well-informed engagement in the British political processes by encouraging voter registration, also publishing Electing to Listen: promoting policies for British Muslims in June 2001 (Peedziwiatr 2007, p. 276).

Internationally major geo-political events and foreign policy continued to overshadow the discourse for British Muslims in the MCB's early years, including the Kosovan War 1998-1999, the 9/11 terrorist attacks in the US and the subsequent invasions of Afghanistan and Iraq. However, this period also saw the emergence of Muslim individuals ${ }^{2}$ and community groups aligning themselves with other non-religious and socio-civic organisations that were united with the sole purpose, for example, of preventing the war in Iraq, with protests including British Muslim men, women and children (as seen with the Million People March) ${ }^{3}$. As Elshayyal explains, many young Muslims turned to grassroots community group and joined the Stop the War Coalition to protest against the Iraq War-thus demonstrating a shift away from communal to national alliances based upon shared values and ideas (Elshayyal 2015). This was a significant development in the political 'coming of age' of British Muslims. Anti-war campaigning mobilised many of them to be active alongside non-religious and even secular actors, thus encouraging many to be political outside Muslim organisations. This is echoed by Elshayyal when she observed, many that moderate thinkers during this period not only explained how the Muslim community felt it needed to provide vision and direction to wider society, but essentially the onus lay upon emphasising and increasing civic participation (Elshayyal 2015, p. 178).

Set against this background, the MCB's early leadership emerged fresh with its own plans to develop the organisation internally, albeit buffeted by events abroad and the need to express the strong feeling of Muslim communities on these issues (MCB 2002, p. xvi). These multiple roles included applying pressure on the Prime Minister at the Commonwealth Institute in 1998 during the ongoing conflict in Kosovo, alongside Muslim parliamentarians and the foreign ambassadors of Muslim majority countries. The issues of human rights abuses in Chechnya, Iraq, Palestine and Kashmir were regularly mentioned in various Secretary General speeches addressing the Prime Minister ${ }^{4}$ and the Foreign Secretary ${ }^{5}$.

The wide range of issues that the MCB's early leadership were concerned about is reflected in the Working Committees that were established. Specialists were brought in to advise on International Affairs, Social and Family Affairs, Women, Business and Economics, Media, and Education, to name a few. These specialist committees led to several successful campaigns. For example, working alongside the Association of Muslim Schools, the MCB was successful in campaigning for Muslim faith schools to have equal access to grant-maintained status. This was finally achieved in 1998 with Islamia Primary School in London and Al Furqan Primary School in Birmingham (despite the first applications

2 A high profile example was Salma Yaqoob a Birmingham psychotherapist who was a member of Stop the War Coalition and later Respect Party.

3 “'Million” March against Iraq War', 16 February 2003, http://news.bbc.co.uk/1/hi/uk/2765041.stm, accessed 4 June 2019.

4 Iqbal Sacranie, 'Secretary General's Address at Reception for Prime Minister', 5 May 1999. http://www.mcbrestore.org.uk/ secretary-generals-address-at-reception-for-prime-minister/ (accessed 8 May 2019).

5 Iqbal Sacranie, 'Welcome Speech by Iqbal Sacranie, Secretary General Muslim Council of Britain, at a Reception in Honour of Mr Peter Hain MP, Minister of State for Foreign Office and Commonwealth Affairs', London, November 1999. https://mcb.org.uk/press-releases/welcome-speech-by-iqbal-sacranie-secretary-general-muslim-council-of-britain-at-areception-in-honour-of-mr-peter-hain-mp-minister-of-state-for-foreign-office-and-commonwealth-affairs-london-4-no (accessed 8 May 2019). 
being submitted to the Department for Education in 1986) ${ }^{6}$. Another successful campaign was the four-year long lobbying efforts by MCB to include a question on religious affiliation in the 2001 Census (Hussain and Sherif 2014, p. 418). This was a seminal milestone that enabled a significantly greater understanding of faith communities in British society, and provided a data-driven evidence base for future policy makers and researchers (Sherif 2011).

Taken together these initiatives demonstrated sophistication in the way British Muslims were now increasingly engaging in public life, lobbying for their interests and shaping public policy in a way that centred on equal—not preferential—-treatment alongside other faith minorities. As Sherif explains, not only did this process demonstrate the "creation of alliances and the importance of interfaith action for social action", but "marked the emergence of new and welcome social developments for the 21st Century" (ibid: 16).

\section{Contemporary Developments, Function and Governance}

Representative umbrella bodies exist in several sectors, whether it is the Confederation of Business Industry (CBI) which represents 1500 direct members from a broad cross-section of the UK business community, to Universities UK which describes itself as an advocacy organisation representing 136 universities nationwide. Thus, what umbrella bodies have in common is that their members are organisations-as opposed to individuals. In any sector, the role of a representative and membership-based body is generally to provide three key functions: (a) represent the voice of its members, (b) advocate on issues that matter to its members and (c) capacity building and sharing of best practice between its members.

In many ways, the strengths and weaknesses of the MCB-as with any other representative body serving a membership base-are reflective of the strength and weakness of British Muslim civil society as a whole. Despite the long history of Muslim settlement in the UK, it is important to recognise that Muslim communities are still developing their infrastructures and capacities.

The structural arrangements of the MCB play a significant role in its governance and in ensuring fair and equal representation. As a democratic umbrella body, the MCB is reliant on its members for direction and guidance-otherwise known as its affiliates. Affiliates have diverse backgrounds and represent various ethnic and sectarian groups. Since its foundation in 1997, the MCB Annual General Meeting organised every year provides an opportunity for delegates from all member organisations to hold the MCB to account for its actions, and to discuss future ideas and events. Every two years, an election is held at the AGM; positions of governance are allocated through an electoral process whereby all present delegates (representing registered affiliates) are entitled to a vote on who should be elected to the National Council (NC) and the posts of Secretary General (SG) and Deputy Secretary General (DSG).

The National Council is comprised of 50 to 60 individuals who represent the current 500 affiliates that constitute the MCB. These individuals are key to holding MCB to account on a quarterly review basis and they come from a range of backgrounds. The SG and DSG are directly elected at election AGMs with the remaining five office bearers nominated by the SG and then put forward for ratification by the NC. All Office Bearers perform their role in a voluntary capacity. These individuals, alongside an Executive Committee who are responsible for the day-to-day governance of the MCB are therefore held to account by the affiliates through this democratic process. In keeping with the emphasis on consultation (shura) in Islam, MCB's internal decision-making is strongly influenced by a consensus-based ethos, with best endeavours made to genuinely listen to the views of all relevant stakeholders before a practical way forward is proposed and agreed upon. The arrangements that underpin the MCB's structures of governance mean that there are rigorous 'checks and balances' in place to ensure that the organisation delivers on its mandate to its grassroots members.

6 'BBC News|UK|Government Agrees to Fund Muslim Schools'. http://news.bbc.co.uk/1/hi/uk/46069.stm, accessed 7 June 2019. 
MCB affiliates pay an annual membership fee, thus providing a financial base and generating 'buy in' from member bodies. Membership fees are graded from $100 \mathrm{GBP} /$ year for organisations with an annual turnover of less than $£ 100,000$, to $5000 \mathrm{GBP} /$ year for annual turnovers of greater than $15 \mathrm{~m} \mathrm{GBP}^{7}$, although the vast majority of MCB's 500 members fall in the lower membership fee bands. This situation creates interesting challenges of perception. Many might assume the MCB has significant financial and human capacity, but a basic review quickly reveals the reality that income from membership fees barely covers the salary of one full-time administrator and rent for a small office space in London.

Whilst the MCB has always been a democratic body, changes have been implemented over the years to increase the accessibility and transparency of its arrangements. This was most evident in 2010 following criticism of the previously private process through which the Secretary-General was elected by National Council members only. As a result, changes were made to the constitution to ensure that candidates for the SG and DSG roles were publicly announced and voted on directly by delegates of affiliates at election AGMs instead.

Another important change relating to member finances was also initiated in 2012. Whereas affiliate organisations were previously charged a set fee irrespective of size or income, new arrangements were made enabling each organisation to make membership payments depending on their size, resources and revenue ${ }^{8}$. Today, approximately one-third of MCB funding comes from membership fees, with the remainder still coming from community donations, fundraising events and the award of capacity-building and project grants. However as explained by Radcliffe with regards the past, "MCB has consistently suffered from inadequate funding, with its leaders often paying for business expenses out of their own pocket" (Radcliffe 2004, p. 371).

For much of the last 30 years, British Muslim civil society has been dominated by South Asian, Sunni male 'elders'. It has taken time to transit to a more youthful and diverse representation of Muslim community organisations that better reflects demographics such as age, gender and countries of origin. And the profile of the MCB Executive Committee today reflects this progress. The current twelve Executive Committee members who take responsibility for day to day governance include four women, three from a Shia background, and two of African heritage. The average age is significantly younger than those of previous leadership teams; in 2018 the Deputy Secretary General aged 28 years old was the youngest MCB Office Bearer to ever be elected ${ }^{9}$.

Over the course of its history, the MCB has worked hard to ensure that its governance structures continue to accurately reflect the ethnic diversity of British Muslim communities. While nearly two-thirds of British Muslims are of South Asian origin, it remains the case that the MCB has also actively involved Muslims who originate from Arab, African, Afro-Caribbean, and other ethnic backgrounds. Similarly, converts to Islam from white or other ethnic backgrounds are also now finding their place in the structures of the MCB, thereby ensuring that their needs and perspectives are reflected in the work of the organisation. The extent to which the organisation is committed to internal diversity is apparent in its recent efforts to challenge the 'quiet' prejudice that sometimes exists in South Asian communities towards African and Afro-Caribbean groups. The MCBs 'Proudly Muslim and Black' initiative sought in February 2019 to bring the history, heritage and socio-civic contributions of Britain's African and Afro-Caribbean communities from the margins to the mainstream.

As a cross-sectarian representative body, MCB has always taken Sunni-Shia intra-faith relations seriously, from ensuring Shia-led organisations were represented at the MCB's founding consultations,

7 https://mcb.org.uk/join-mcb/.

8 The Muslim Council of Britain, 'MCB Affiliation Pack', 2014, www.mcb.org.uk/wp-content/uploads/2014/09/Affiliation-Pack. pdf, accessed 12 June 2019.

9 'Youngest Deputy Secretary General Elected at Muslim Council's 21st Annual General Meeting (AGM)', Muslim Council of Britain (MCB) (blog), 10 July 2018, https://mcb.org.uk/press-releases/youngest-deputy-secretary-general-elected-at-muslimcouncils-21st-annual-general-meeting-agm/, accessed 22 June 2019. 
meetings and affiliate base, to day-to-day working together as Executive Committee and National Council members. In particular, as geopolitical events abroad contributed to rising tensions amongst some communities at home, the MCB issued statements condemning sectarian-driven vandalism of mosques in the UK and led on the symbolic signing of an Intra-Faith Unity Statement at its 2013 AGM $^{10}$.

The election in 2016 of the MCB's first British-born Secretary General was a watershed moment; for the first time the elected Secretary General was a British-born Muslim ${ }^{11}$. This effectively proved a marker for the transition of leadership in British Muslim communities from first generation migrants, to the maturity of second and third generations Muslims born and bred in the UK. As with all Muslim civil society organisations-whether mosques, schools, charities, or professional networks-the transition in leadership from the founding cohort to the successor generation was only a matter of time. Like much organisational change, it was a hard-won and challenging process, and one that is much needed for other Muslim-led civil society organisations to address lingering negative perceptions of being 'old boys clubs'. The MCB is committed to continuing to support the leadership talents of young British-born men and women in order to ensure that it remains representative, forward-facing, and responsive in the service of its affiliates, and by extension, British Muslim communities.

According to the Charity Commission, men outnumber women on the boards of all charities in England \& Wales by two to one, and anecdotally the discrepancy is higher in the Muslim sector ${ }^{12}$. Cultural attitudes amongst many Muslim-led organisations about the role of women have been stubbornly 'conservative'. The MCB sees its role as leading by example in these matters (Jones et al. 2015, p. 12). Notably, aside from a quarter of the current Executive Committee being female, a constitutional amendment in 2012 passed to ensure that at least $20 \%$ of the elected National Council was female ${ }^{13}$. And with the launch of the MCB's annual 'Women in Mosques Development Programme' in 2018 ${ }^{14}$, calls for more Muslim-led organisations in Britain are being reinforced, to ensure they nurture and include talented Muslim women in leadership roles ${ }^{15}$.

These developmental processes continue to evolve today with the social activism of third generation British Muslims. Youthful Muslims such as university students and young professionals, empowered by the tools of social media, are actively lobbying, rallying and campaigning to change society for the better, while using existing faith and non-faith institutions. As Elshayyal explains, the turn of the century saw many more young Muslims mobilising with a greater sense of confidence and sophistication in their identity and actions (Elshayyal 2015, p. 180). One example is young Muslim men and women becoming fundamental to the student politics scene, including two elected Muslim female presidents of the National Union of Students (NUS) ${ }^{16}$.

But the increasingly prominent role of young Muslims in civil society activism, within and outside the $\mathrm{MCB}$ is not surprising when the changing demographics of British Muslim communities are taken into account. Figures from the most recent Census in 2011 show that almost 50\% of British Muslims are under 24 years old (compared to $30 \%$ in the general population) and $48 \%$ are born in the UK

10 'Intra-Faith Unity Statement Aims to Provide Common Ground Between Muslims of All Traditions', Muslim Council of Britain (MCB) (Statement), 29 June 2013, https://mcb.org.uk/mcb-updates/british-muslims-sign-historic-intra-faith-unity-statement/.

11 'East End Boy Becomes Muslim Council's First British-Born Leader', The Times, 30 July 2016, sec. News, https://www. thetimes.co.uk/article/east-end-boy-becomes-muslim-councils-first-british-born-leader-7r62x5rr2, accessed 22 June 2019.

12 'Charities Must Do More to Promote Diversity on Their Boards, New Research Shows', GOV.UK, accessed 7 June 2019 , https://www.gov.uk/government/news/charities-must-do-more-to-promote-diversity-on-their-boards-new-research-shows.

13 'Islamic Charity to Impose Quota for Women on Its Decision-Making Committee', accessed 7 June 2019, https://www.civilsociety. co.uk/news/islamic-charity-to-impose-quota-for-women-on-its-decision-making-committee.html.

14 'Muslim Council of Britain to Train Women to Run Mosques', The Guardian, 4 October 2018, sec. World news, https: //www.theguardian.com/world/2018/oct/04/muslim-council-of-britain-women-leadership-training.

15 'Muslim Council Calls for More Muslim Women in Leadership Roles', Muslim Council of Britain (MCB) (blog), 1 April 2019 , https://mcb.org.uk/press-releases/muslim-council-calls-for-more-muslim-women-in-leadership-roles/.

16 'Zamzam Ibrahim Elected as NUS President', The Independent, 10 April 2019, https://www.independent.co.uk/news/ education/education-news/zamzam-ibrahim-nus-president-national-union-students-election-racism-fees-a8863261. html. 
(i.e., second generation onwards) ${ }^{17}$. The total number of British Muslims also increased from $1.55 \mathrm{~m}$ in 2001, to $2.7 \mathrm{~m}$ in 2011, with latest polling data suggesting the number is currently at circa $3.5 \mathrm{~m}$, which amounts to approximately $6 \%$ of the overall British population ${ }^{18}$. It is interesting to note that whilst the Satanic Verses affair is an event often considered a watershed moment in defining the British Muslim experience, an estimated two-thirds of British Muslims alive today were either not born at that time or were still young children.

Internationally, the challenge of providing national representative voices for Muslims has been tackled in different ways across different nations, with the MCB seeking to learn and share lessons from the UK where relevant. For example, the National Mosque Open Day programme run by Australia's Lebanese Muslim Association helped to inform the MCB's \#VisitMyMosque campaign in its early years and vice versa, while members of the Islamic Council of Norway (IRN) attended the most recent Our Mosques Our Future conference in 2019. Further lessons can be learnt between Muslim umbrella bodies internationally from the likes of the Islamic Society of North America and Council on American-Islamic Relations in the US, to the National Council of Canadian Muslims, to closer to home in Europe with the French Council of the Muslim Faith (CFCM) and the Coordinating Council of Muslims (KRM) in Germany.

\section{External and Internal Perceptions}

Over the course of its history, the MCB has had to manage some difficult public relations. These have often centred on presumptions made about its ideological roots. What is most notable about these challenges is the tendency to make selective use of out-of-date information, and the lack of any real supporting evidence for claims that have been made. This indicates an overall lack of nuanced understanding of British Muslim communities and their origins, and insufficient 'religious literacy' when it comes to the Islamic tradition itself. Thus, the MCB has sometimes been accused of being 'Islamist' or dominated by the Muslim Brotherhood. Authors such as Innes Bowen in the book Medina in Birmingham, Najaf in Brent-Inside British Islam, asserts with certainty the that the MCB was dominated by those aligned to the Jamaat-e-Islami (a political party based in Pakistan and Bangladesh) and wonders whether the label moderate is apt to describe MCB (Bowen 2007, pp. 89-90). These accusations were as incorrect then as they are now, with the current MCB leadership team more likely to self-identify by their profession, or where they grew up in the UK, rather than by school of thought or ideology (Pedziwiatr 2007, p. 273). Furthermore, it is notable that during the history of the MCB, imams and religious scholars have in fact had relatively little involvement in core decision-making roles. Limiting their contributions largely to advisory or consultative levels has perhaps helped to ensure that the MCB continues to represent the interests of Muslims from a wide range of theological schools of thought.

Claims such as Bowen's fail to place the MCB in its contemporary context by making proper references to its press statements, its projects, activities and leaders. Media commentators who take time to engage more deeply with the $\mathrm{MCB}$ would find an open, progressive civil society umbrella organisation engaged in the spectrum of British social and political life. If it were the case that the MCB was only serving the narrow interests of one particular group within British Muslim communities, its affiliates would have undoubtedly reacted by leaving and/or using its democratic structures to change the leadership (Jones et al. 2015, p. 9).

Prior to 2005, the MCB had good relations with central government. The friendly rapport that the MCB had with the New Labour government in its early years was by no means unique. In fact, according to Radcliffe, many socio-civic and human rights organisations were called upon to provide

17 BMIN, Muslim Council of Britain (MCB) (Special Report), January 2015, http://www.mcb.org.uk/wp-content/uploads/2015/02/ MCBCensusReport_2015.pdf.

18 BMIN, Muslim Council of Britain (MCB) (Special Report), January 2015, http://www.mcb.org.uk/wp-content/uploads/2015/02/ MCBCensusReport_2015.pdf. 
consultations to the government around this time. For example, organisations such as Amnesty International 'provided briefings to new ambassadors on human rights training and respective courses for civil servants' (Radcliffe 2004, p. 366). From 1997-2000, government consultations were relatively common; by encouraging Muslims to get involved in politics, government officials thereby gained access to Muslim communities, in return. As a result of this process, the Labour Party became more dependent upon the Muslim vote in some constituencies, with Muslims making up a significant proportion of their voters. As Elshayyal explains, "the experience of working with the Left served to broaden the political experience of many within the Muslim community and accelerated the pace at which the level of mainstream political engagement intensified" (Elshayyal 2015, p. 186). The extent of this can also be seen with inaugural MCB Secretary General receiving an OBE (1999) and subsequently a Knighthood (2005) in a period when these awards were less common among Muslim and other minority communities. However, the cordial relations that existed changed in the post-9/11 landscape and with the announcement of the Iraq War in 2003. The MCB publicly opposed the war and refused to agree with the Labour Party's foreign policy.

The period after the $7 / 7$ attacks signaled a further turning point in relations between the government and British Muslim communities, including with the MCB. After the attacks, the government established the Countering Violent Extremism group (2005) which was focused on liaising with community groups and organisations around issues relating to radicalisation and extremism. This process saw the MCB and various other Muslim organisations working with the government to create legislation and policy ideas on tackling the risks posed by terrorism and radicalisation. However, as time progressed, it became evident that rather than being a productive relationship, the lens of securitisation was causing Muslim communities to be viewed as suspects rather than stakeholders. This led many Muslim organisations to disassociate themselves from the process.

MCB public relations were also affected by the controversy arising from its early stance to the marking of Holocaust Memorial Day (HMD) given the lack of attention afforded to the genocide of Muslims in Bosnia only a decade earlier, a stance which was rightfully corrected in 2010. Difficulties further increased following Operation Cast Lead in 2008 which saw the 'Istanbul Convention and Declaration' being signed in an independent, personal capacity by the then MCB Deputy Secretary General. This sparked media outrage with elements of the tabloid press wildly extrapolating that this signing meant MCB condoned attacks on or the killing of British troops. This incident led to an exchange of letters between the then Secretary of State at the Department for Communities and Local Government (DCLG), who condemned the signing. She insisted on the DSG's resignation from the $\mathrm{MCB}$ and indicated that refusal would lead to the breaking of ties with the government. Not only did this have an impact on the external perception of the MCB, which led to breakdown of relations, but the incident was also a catalyst for reviewing MCB internal procedures. The MCB prepared additional internal governance protocols on what Office Bearers could and could not do, even in a personal capacity. In a parallel move, the MCB issued a document highlighting the historical contributions of British Muslims to the UK Armed Forces ${ }^{19}$. But it is important to note that this was not done solely in the context of this particular controversy as from its inception, the MCB has campaigned for better Muslim representation in all walks of life, including the Armed Forces. For example, the MCB successfully campaigned for the military to appoint its first ever Muslim Chaplain in 2005 and encouraged the subsequent creation of the Armed Forces Muslim Association.

By 2009, government ties with the MCB were re-established with the appointment of a new Secretary of State at DCLG. During this time, cabinet ministers and senior secretaries of state attended MCB events, such as the inaugural Muslim Leadership Dinner. But after the 2010 election, the situation changed once again under the new Conservative-led coalition government. Even though the MCB met

19 'A report exploring the contributions of British Muslims in the military', Muslim Council of Britain (MCB) (Special Report), Spring 2009, https://mcb.org.uk/wp-content/uploads/2014/04/RememberingtheBrave_MCB.pdf, accessed 12 June 2019. 
several times with several Liberal Democrat ministers up to 2015, the influence of neoconservatives close to 10 Downing Street, and who were dismissive of Muslim representation, meant that government interactions with the MCB scaled down significantly. With several government departments seeking alternative organisations with different 'ideological inclinations' for consultations on matters affecting Muslim communities, and it was felt less attention was placed on grass roots community engagement.

In the last few years, this process has once again changed, with some departments and civil servants consulting with the MCB and engaging with the organisation on a variety of levels, with an example being on conversations surrounding religious slaughter and the issues surrounding religious burials. It seems that rather than maintaining official, high profile and public relationship, as before, there was a more ad hoc approach in which the MCB is consulted on specific issues. However, this raises the question that despite this pattern of casual consultation, why has the government refused to engage with MCB and other Muslim organisations on a more formal and consistent level ${ }^{20}$ ? It is of note therefore that in Wales and Scotland, devolved administrations continue to engage formally with MCB's regional affiliates, the Muslim Council of Wales and Muslim Council of Scotland respectively. It is only the Conservative-led Westminster administration that has more or less maintained a quasi-boycott approach since 2010.

More recently, the MCB has advocated policy change in relation to extremism and terrorism. When the government finally announced its plans for an Independent Review of Prevent in 2019, the MCB indicated its support for this welcome move. For its part, the MCB undertook a National Listening Exercise in 2019, which involved collating accounts of the myriad ways in which counter-terrorism legislation had affected British Muslim communities at the grassroots level. The intention is that the evidence will feed into improved policy, not only in relation to political violence but also far-right extremism which is likely to be more seriously addressed in any future iteration of counter-terrorism policies.

Alongside the MCB's work in relation to social policy, it has initiated successful projects that go beyond 'identity politics' and address the interests of Muslim communities in civil society more broadly. Recent examples include the national \#VisitMyMosque project, an annual campaign encouraging mosques across Britain to hold open days to welcome visitors and neighbours of all faiths and none. With just 20 participating mosques in 2015, it grew to over 250 mosques getting involved by 2019 . The grassroots community engagement that this campaign has cultivated has led to other projects including inviting mosque leaders to meet, network and share best practice at the 'Our Mosques, Our Future' series of conferences.

MCB's media monitoring work, initially a voluntary personal effort by a former MCB Assistant Secretary General ${ }^{21}$, who took on the personal responsibility to submit complaints about factually incorrect reporting of Islam and Muslims in the British media has now been formalised into the Centre for Media Monitoring. This has increased the capacity of Muslim communities to engage with TV, radio, online and print media outlets at both national and local levels in a proactive and constructive way, rather than resort to the 'the media is against us' narrative. Since the summer of 2018, the MCB has led the calls for an inquiry into Islamophobia in the Conservative Party. This has raised the issue up the political agenda and onto the newspaper front pages. This move has been welcomed by many Muslim communities concerned by the continuing rise of Islamophobic sentiment in small pockets of British society, particularly following the Brexit referendum in 2016.

Despite many successes, the MCB recognises that further efforts are required to increase its capacity to act with decisive leadership and to continue to renew how it provides representation in a

20 'Muslim Council of Britain: No one to talk to, A Muslim group falls from favour, The Economist, 18 Oct 2014, sec. Britain, https://www.economist.com/britain/2014/10/18/no-one-to-talk-to, accessed 14 May 2019.

21 'One man's (very polite) fight against media Islamophobia', The Guardian, 18 Oct 2018, sec. The Long Read, https: //www.theguardian.com/news/2018/oct/18/miqdaad-versi-very-polite-fight-against-british-media-islamophobia, accessed 12 June 2019. 
way that is accurate as well as relevant vis a vis its members (Dobbernack 2017, p. 18). Aspiring to fully empower British Muslim communities in their engagement with public life is a particular challenge in relation to the approximate more than double increase in the size of the Muslim population between 1997 and 2019. The resources required in terms of advocacy, membership engagement, public affairs and media liaison, as well as new projects must scale up accordingly, if the MCB is to keep apace.

In relation to internal Muslim community perceptions, two independent polls in 2015 show that the majority of British Muslims believe the MCB is successful in representing their views. Fifty-five per cent of those questioned in a COMRES poll commissioned by the BBC agreed with the statement, "The Muslim Council of Britain does a good job representing the views of Muslims"22. An ICM poll commissioned by Channel 4 indicated 51 per cent support of the statement: "To what extent do you agree or disagree that the Muslim Council of Britain represents your views?"23. Aside from the data derived from grassroots polls, numerous individuals and activists frequently express support for MCB's work-publicly and privately-despite differences of opinion that may exist on any given topic (Seddon 2014, p. 228). Ironically, the period during which the MCB was out of favour with government may have inadvertently increased Muslim community support for it, reinforcing positive perceptions and understanding of its independence and legitimacy.

In summary, it is evident that the work of the MCB has been integral in shaping aspects of public policy in Britain and making sure that this has a positive impact on the lives of minorities in Britain (Pedziwiatr 2007, p. 274). Following the campaign for inclusion of a question on religion in the 2001 Census, the MCB has subsequently built upon this work by comparing 2001 and 2011 data. This resulted in the report 'British Muslims in Numbers' ${ }^{24}$, which provided a comprehensive picture of the demographics of Muslim communities. The information produced revealed some stark contrasts, from the over-representation of Muslims in prisons and the lowest income levels of any faith community, to the higher than average number of Muslim graduates and doctors. The information produced by the MCB in the report has been useful for a wide range of audiences both within and outside Muslim communities. The report received widespread media attention, providing academics and policy-makers with the data required to ensure evidence-based understanding of the social policy issues facing British Muslims (Pędziwiatr 2007, p. 275).

Discussions surrounding the understanding of 'halal' meat have also been integral in the work MCB has done in recent years. Under former Secretary Generals, extensive ties developed with Jewish community groups to lobby regarding religious slaughter in the UK. Despite being a non-theological organisation, the MCB has managed to understand the sensitivities and issues surrounding halal meat slaughter within its communities and has actively worked to make sure all perspectives are recognised. The MCB has necessarily consulted with religious scholars on this issue as needed, but in keeping with its ethos and role, and mindful of the diversity of its constituent membership, it has not engaged in matters of theological debate as a routine part of its work.

\section{Conclusions}

So are representative Muslim bodies, such as the MCB, progressive interlocutors or redundant gatekeepers? It has often acted successfully as a progressive mediating body, lobbying for the interests of Muslim communities both within and beyond its membership circles. This paper has documented many of its campaigns and initiatives, and equally has attempted to convey the well intentions that have underpinned these efforts. Notably, Muslim communities in Britain have been successful in

22 COMRES, 2015 Muslim Poll—Do You Agree or Disagree with These Statements about British Society ...?', http://comresglobal. com/wp-content/uploads/2015/02/BBC-Today-Programme_British-Muslims-Poll_FINAL-Tables_Feb2015.pdf, accessed 7 June 2019.

23 'Facts about $\mathrm{MCB}^{\prime}$, Muslim Council of Britain (MCB) (blog), https://mcb.org.uk/about/facts-about-mcb/, accessed 7 June 2019.

24 BMIN, Muslim Council of Britain (MCB) (Special Report), January 2015, http://www.mcb.org.uk/wp-content/uploads/2015/02/ MCBCensusReport_2015.pdf, accessed 18 June 2019. 
establishing other civil society and professional bodies that are perfectly capable of 'speaking for themselves', and do so as a matter of course (Jones et al. 2015, p. 14).

Over the course of its history, the MCB has faced critique and misunderstanding from both within and outside Muslim communities. But with growing maturity and confidence, it has come to recognise the value of the 'long view' and the fact that the results of its work are often intangible and long-term. Notably, throughout all its work, MCB continuously strive to ensure it reflects the wide richness of Britain's diverse Muslim communities across the spectrums of age, gender, geographic location, ethnic background and school of thought. Its genesis and subsequent flourishing have taken place against the backdrop of difficult internal and external politics and international events, under a constant and often negative media gaze, and subject to the changing priorities of successive governments. For an organisation with limited resources and driven largely by volunteers, it is a testament to its founding vision and cultivation of a servant-leadership approach that it has managed to remain vibrant, outward-facing, engaged and self-critical. Over the course of time, it has managed to navigate a difficult tension between being responsive to the needs and demands of its affiliates at the grassroots (Bech 2010, p. 17), while also being proactive and forward-thinking in its strategy for the benefit of not only Muslim communities, but British society as a whole. Its efforts continue to be guided by its mission statement, namely, 'empowering Muslim communities towards achieving a just, cohesive and successful British society.'

Author Contributions: H.K. and H.J. contributed equally to the different tasks and parts of the paper, while Z.A. provided research assistance. All authors have read and agreed to the published version of the manuscript.

Funding: This research received no external funding.

Conflicts of Interest: The authors declare no conflict of interest.

\section{References}

Bari, Muhammad Abdul. 2018. A Long Jihad: My Quest for the Middle Way. Leicester: Kube Publishing Limited.

Bech, Emily Cochran. 2010. From Blowback to Incorporation: Muslim Council Consolidation and Influence in Europe. Conference Paper. Chicago: Midwest Political Science Association Chicago.

Bowen, Innes. 2007. Medina in Birmingham, Najaf in Brent: Inside British Islam. London: Hurst \& Company.

Dobbernack, Jan. 2017. Making a presence: Images of polity and constituency in British Muslim representative politics. Ethnicities 19: 292-310.

Elshayyal, Khadijah. 2015. From crisis to opportunity: 9/11 and the progress of British Muslim political engagement. In Muslims and Political Participation in Britain. Edited by Tim Peace. Routledge Studies in Religion and Politics. London: Routledge, pp. 174-92.

Gilliat-Ray, Sophie. 2010. Muslims in Britain: An Introduction. Cambridge: Cambridge University Press.

Hussain, Serena, and Jamil Sherif. 2014. Minority religions in the census: The case of British Muslims. Religion 44: 414-33.

Jones, Stephen H., Therese O'Toole, Daniel Nilsson DeHanas, Tariq Modood, and Nasar Meer. 2015. A 'System of Self-appointed Leaders'? Examining Modes of Muslim Representation in Governance in Britain. The British Journal of Politics and International Relations 17: 207-23. [CrossRef]

MCB, ed. 2002. The Quest for Sanity: Reflections on September 11 and the Aftermath. London: MCB.

McLoughlin, Seán. 2005. The State, New Muslim Leaderships and Islam as a Resource for Engagement in Britain. In European Muslims and the Secular State. Edited by Jocelyne Cesari and McLoughlin Sean. Aldershot: Ashgate, pp. 55-70.

NICMU. 1996. National Interim Committee on Muslim Affairs (NICMU) Survey. London: NICMU.

Nielsen, Jørgen S. 2004. Muslims in Western Europe. Edinburgh: Edinburgh University Press.

Pędziwiatr, Konrad. 2007. Creating New Discursive Arenas and Influencing the Policies of the State: The case of the Muslim Council of Britain. Social Compass 54: 267-80. [CrossRef]

Radcliffe, Liat. 2004. A Muslim Lobby at Whitehall? Examining the role of the Muslim Minority in British Foreign Policy Making. Islam and Christian-Muslim Relations 15: 365-86. [CrossRef] 
Seddon, Mohammad Siddique. 2014. The Muslim Council of Britain: From pious lay preaching to political lobbying. In Islamic Movements of Europe: Public Religion and Islamophobia in the Modern World. Edited by Frank Peter and Ortega Rafael. London: IB Tauris, pp. 226-29.

Sherif, Jamil. 2011. A Census chronicle-Reflections on the campaign for a religion question in the 2001 Census for England and Wales. Journal of Beliefs and Values 32: 1-18. [CrossRef]

UKACIA. 1993. Muslims and the Law in Multi-Faith Britain: Need for Reform. London: UKACIA.

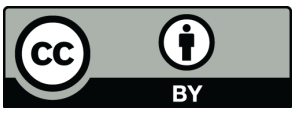

(C) 2020 by the authors. Licensee MDPI, Basel, Switzerland. This article is an open access article distributed under the terms and conditions of the Creative Commons Attribution (CC BY) license (http://creativecommons.org/licenses/by/4.0/). 